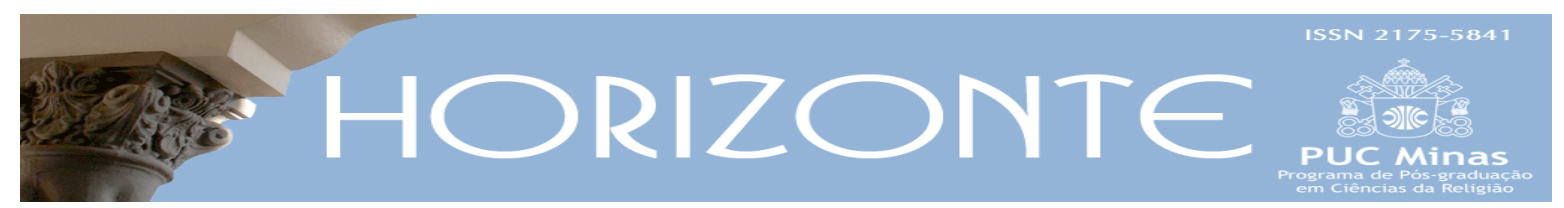

Dossiê: Narrativas Sagradas e Linguagens Religiosas - Artigo Original ๑。

DOI - 10.5752/P.2175-5841.2016v14n42p337

\title{
El nuevo paradigma arqueológico-bíblico
}

\author{
The new archaeological biblical paradigm
}

José Maria Vigil*

\begin{abstract}
Resumen
Después de una época clásica de esplendor en la primera mitad del siglo pasado, la arqueología interesada por la investigación sobre el judeocristianismo se ha transformado profundamente, hablándose, con diferentes enfoques, de una Nueva Arqueología. El autor llama nuevo paradigma arqueológico, figuradamente, al conjunto tanto de esos nuevos enfoques como de los llamativos hallazgos arqueológicos encontrados, que desafían fuertemente la historicidad de hechos y de figuras bíblicas importantes, así como de la historia misma de los pueblos que han habitado secularmente la tierra palestina-israelí. La presentación de estos hallazgos hace hincapié especial en lo que llama "el relato detrás del relato", las vivencias histórico-existenciales del pueblo que elaboró los relatos y tradiciones tanto del Primero como del Segundo Testamento, deteniéndose concretamente en explicitar lo que está en juego en la aceptación de este desafío de la nueva arqueología. En la parte final el autor esboza pistas de reflexión, desde la perspectiva de las ciencias de la religión, acerca del profundo y múltiple replanteamiento múltiple al que este nuevo paradigma arqueológico parece invitar.
\end{abstract}

Palabras clave: Biblia, arqueología bíblica, nueva arqueología, nuevo paradigma arqueológico, historicidad, relato por detrás del relato.

\begin{abstract}
After a classic heyday in the first half of the last century, archeology interested in research on JudeoChristianity was profoundly transformed, talking, from different approaches, on a New Archaeology. The author calls "new archaeological paradigm", figuratively, this set of both these new approaches and these striking archeological findings, which strongly challenge the historicity of facts and important biblical figures, as well as the very history of the peoples who have inhabited for centuries IsraeliPalestinian land. The presentation of these findings strongly emphasizes what he calls "the story behind the story", historical existential experiences of the people who developed the textual stories and traditions of both the First and the Second Testament, trying specifically to explain what is at stake in accepting the challenge of this archeology of new paradigm. In the final part, the author outlines some reflections, from the perspective of the science of religion, about the deep and multiple rethinking that this new paradigm seems to invite.
\end{abstract}

Keywords: Bible, biblical Archaeology, new archaeology, new archaeological paradigm, historicity, the story behind the story.

Artículo recibido el 8 de diciembre, 2015 y aprobado el 28 de junio de 2016.

* Doctor em Educación, con especialidad en mediación pedagógica - Universidad La Salle, de San José de Costa Rica (2008). País de Origem: Panamá. E mail: horizonte.pucminas@gmail.com

Horizonte, Belo Horizonte, v. 14, n. 42, p. 337-376, abr./jun. 2016 - ISSN 2175-5841 


\section{Introducción - ¿Un nuevo paradigma en arqueología?}

Desde hace pocas décadas se habla de una Nueva Arqueología (DEVER 2001b, p. 53-96, cap. 3), de "el final de la 'arqueología bíblica”, sustituida ahora por una arqueología laica y emancipada (THOMPSON apud DAVIES, 1996, p. 26 y 28); se habla también de una arqueología pos-procesual (HODDER; HUDSON, 2003, p. 206ss), posmoderna (DEVER, 2001b, p. 23ss, cap. 2), o de una "Nueva Visión Arqueológica” (FINKELSTEIN; SILBERMAN, 2001, p. 4-24, más el propio subtítulo del libro). A todo ello es a lo que nos queremos referir en este estudio cuando hablaremos, de un modo global, sobre un "nuevo paradigma arqueológico". Más adelante explicaremos en qué puede ser cifrada concretamente la novedad de este "nuevo paradigma", pero en pocas palabras se puede decir que se trata simplemente de la evolución y maduración de estas disciplinas científicas, la arqueología y las ciencias críticas del pasado histórico-bíblico. Nos estamos refiriendo pues también a la "nueva comprensión” histórico-arqueológica de la historia de Israel, y de la historia del surgimiento del cristianismo, que conlleva un replanteamiento radical de las bases históricas sobre las que se puedan considerar fundamentadas tanto las religiones abrahámicas, como la teología cristiana, y la identidad judía o la del Estado de Israel.

Usamos pues la denominación "nuevo paradigma arqueológico bíblico" en un sentido figurado pero real, que abarca varios aspectos. Lo hacemos así porque nos parece que el replanteamiento radical de la visión de estas bases históricas merece ser considerada como uno más de los varios "Nuevos Paradigma” que afectan al pensamiento humano en la actualidad ${ }^{1}$.

Diríamos que la nueva arqueología científica nos presenta una "nueva información” que contradice aquella sobre la que se apoyaban diferentes creencias (religiosas, étnicas, culturales, identitarias). Por lo que a la religión se refiere, esta situación podrá interpretarse claramente como un nuevo episodio de conflicto

\footnotetext{
${ }^{1}$ Véase una "bibliografía de recursos en línea" sobre Nuevos Paradigmas en SERVICIOS KOINONIA, 2016.
} 
entre la ciencia y la fe. La arqueología bíblica clásica apoyaba las creencias religiosas judeocristianas considerándolas fundamentadamente históricas; una nueva generación de arqueólogos, con una arqueología basada en un nuevo paradigma, nos aportan una "nueva información" que desafía frontalmente la historicidad de creencias nuestras fundamentales. Este desafío constituye el objeto y el interés del estudio de este Nuevo Paradigma.

\section{Nuevos procedimientos tecnológicos}

La arqueología científica es una disciplina reciente. Comenzó a mediados del siglo XIX, pero en sus primeras décadas sus actividades estuvieron marcadas por la falta de método y por unos procedimientos de trabajo calificados generalmente como negativos, en cuanto que por donde los arqueólogos hacían sus estudios, iban destruyendo tras de sí todas las pruebas. Sólo a principios del siglo XX podemos decir que encontró y configuró el método que después vendría a ser aceptado por todos, que procede con más rigor en sus registros y deja tras de sí un terreno que todavía muestra parcialmente el registro vertical de lo que ha sido excavado.

Ha sido a lo largo del siglo XX cuando nuevas técnicas han multiplicado las posibilidades de la arqueología con nuevos instrumentos y nuevas posibilidades: hablamos por ejemplo del carbono 14, del método del potasio-argón y otros métodos de datación radiométrica; de la termoluminiscencia para medir la antigüedad de la cerámica; del paleomagnetismo (basando en la inversión de la polaridad magnética de la Tierra); de la fotografía aérea y de diversas formas de geo-radar, que en muchas ocasiones revelan datos del subsuelo; de la racemización ${ }^{2}$ de aminoácidos para la medición de la antigüedad de la materia orgánica... La cerámica se convirtió ya por los años 30 del siglo pasado en el instrumento más utilizado para la datación de la cronología, con unos baremos que

\footnotetext{
${ }^{2}$ Nuevo método de datación química en arqueología. Véase "racemización” en Wikipedia.
} 
pronto se dieron por muy fiables ${ }^{3}$. Pero todas estas nuevas técnicas y la mejora del método arqueológico 4 ha dado a los arqueólogos una enorme capacidad estratigráfica, hasta el punto de que en algunos tells, como el de Meggidó, Israel, se ha llegado a reconocer 26 estratos diferentes en sus restos...

Por otra parte, está el descubrimiento o la interpretación de la mayor parte de las lenguas antiguas, que, a partir del emblemático descubrimiento de la Piedra de Rosetta, nos han hecho accesibles, literalmente legibles, una infinidad de documentos, archivos y bibliotecas antiguas enteras, que hasta hace poco resultaban mudos e ininteligibles.

Con todas estas nuevas capacidades, conseguidas y culminadas la mayor parte de ellas a finales del siglo XX, la arqueología actual ha multiplicado enormemente su capacidad de investigación y de interpretación, y en buena parte, esto ha sido uno de los factores que más ha influido en el surgimiento de lo que con razón se ha llamado una nueva arqueología5.

\section{Nueva arqueología, con un nuevo planteamiento: "cambio de paradigma"}

Se suele decir que fue un francés, Félix de Saulcy (1807-1880) el fundador de la arqueología bíblica, con sus excavaciones, en 1850-1851, en el norte de

\footnotetext{
${ }^{3}$ Fue sobre todo la cronología establecida por W.F. Albright la que se impuso, incluso en la distribución de la cerámica en las salas del Museo Rockefeller, en Jerusalén. No obstante, a pesar de la gran importancia que la cerámica juega en la datación arqueológica, estamos lejos de haber alcanzado una clasificación universalmente aceptada.

${ }^{4}$ A partir de 1960 se ha impuesto el llamado método Wheeler o método Kenyon, nombres de los principales arqueólogos que lo terminaron de perfilar. Consiste en excavar sobre cuadrados de 4 metros de lado, separados por un tabique de un metro, en el que queda el registro vertical de lo que se ha hallado en la horizontal, anotando además exhaustivamente todo lo que se ha ido encontrando.

${ }^{5}$ William DEVER (2001b, p. 53ss) hace un buen elenco de estas nuevas tecnologías al servicio de la nueva arqueología: “Perhaps the most typical aspect of the new archaeology in practice was its interdisciplinary character. This approach, now commonplace on almost all modern excavations, includes such disciplines as geomorphology and geology, paleo-botany and paleo-zoology, climatology and paleo-ecology, hydrology, physical and cultural anthropology, the history of technology, and any number of other specialized branches of the natural and social sciences. Newer techniques for analyzing excavated materials include: radiocarbon and other chronometric means of dating; neutron activation analysis to 'fingerprint' the sources of clays for pottery making and thus to trace trade pat terns; gas chromatography analysis to determine residues present; 'use-wear' analysis of objects using high-powered electron microscopes to define manufacturing techniques, function, and reuse; and, more recently, DNA analysis to identify the relationships between ancient populations and possibly even their long-distance migrations. Technical devices that aid immensely in field excavation and in the workup of materials for publication now include: aerial photography and mapping; geographical information systems, which can model ancient landscapes in detail; electrical-resistivity surveying and ground-penetrating radar; laser transits, which greatly simplify surveying; a whole range of photographic techniques, including digital systems; and a vast array of computer-based systems of recording, data-retrieval, manipulating models, preparing graphics, and even final publication".
}

Horizonte, Belo Horizonte, v. 14, n. 42, p. 337-376, abr./jun. 2016 - ISSN 2175-5841 
Jerusalén. En 1865 se fundó la Palestine Exploration Fund, bajo el patrocinio de la Reina de Inglaterra, con la finalidad de "verificar que la historia bíblica es una historia real, tanto en el tiempo como en el espacio y a través de los acontecimientos, a fin de ofrecer una refutación a la increencia” (BRIEND; ARTUS; NÖEL, 2006, p. 5). Desde sus inicios, la arqueología bíblica se propuso restaurar la confianza respecto al texto bíblico, maltratado por el racionalismo crítico de la exégesis alemana. Una finalidad, pues, interesada, apologética, al servicio de la fe y de la Biblia.

Como es sabido, la mayor parte de las grandes figuras de la arqueología bíblica han sido pastores, sacerdotes, teólogos, profesores de universidades de inspiración religiosa, que vivenciaban su trabajo arqueológico como una prolongación de su vivencia religiosa apostólica personal. Querían demostrar científicamente la verdad histórica de lo que la Biblia narra. Simbólicamente, se suele decir que la arqueología bíblica se hacía "con la piqueta en una mano, y con la Biblia en la otra”. La que guiaba los trabajos de excavación era la Biblia, no el terreno, ni un interés propiamente científico.

Pero ya en la segunda mitad del siglo XX comienza un malestar en esta arqueología "bíblica"6. Si es verdaderamente científica, la arqueología no puede ser "bíblica”, no puede estar regida por criterios religiosos no científicos. Hacia los años 70 empieza a hablarse de "Nueva Arqueología"7, a medida que se implementan por primera vez métodos estratigráficos (tridimensionales) y se vuelve efectiva la citada interdisciplinariedad científica.

En 1968, Niels Peter LEMCHE y Heike FRIIS escriben dos ensayos llamando a una revisión completa de los modos en que se está leyendo la Biblia. Surge la Escuela de Copenhague, o del "minimalismo bíblico”, que propone que la Biblia debe ser leída como una colección de relatos, no como un tratado de historia. T.L.

\footnotetext{
${ }^{6}$ Hoy prefiere hablarse de arqueología siro-palestina, u otra denominación geográfica. Cfr DEVER, 2001b, p. 53ss, cap. 3 (What Archaeology Is and What It Can Contribute to Biblical Studies). Cfr también THOMPSON, T. Dever and the not so new biblical Archaeology. En: DAVIES, P.; FRUTZ, V. (Ed.), 1996, p. 26-28.

${ }^{7}$ DEVER, 2001b, ibid., p. 53ss, cap.3.
} 
THOMPSON ${ }^{8}$, G. GARBINI y Philip R. DAVIES ponen las bases de lo que llegará a ser este minimalismo bíblico. Thompson y Davies ya postulan que el Antiguo Testamento puede ser la creación mítica de una minoritaria comunidad de judíos en Jerusalén, retornados del exilio babilónico, pero son todavía hipótesis, rechazadas por los "maximalistas bíblicos", que aunque aceptan los descubrimientos arqueológicos que resulten probados, sostienen que la Biblia tiene una validez histórica de conjunto. En 1986, J. Maxwell MILLER y John HAYES publican A History of Ancient Israel and Judah, un libro rupturista con una posición clara sobre la no historicidad del éxodo y la conquista de la tierra prometida. En 1988, FINKELSTEIN hace públicos descubrimientos suyos que descalifican también la historicidad de la conquista de la tierra y apunta a que los supuestos conquistadores de esa tierra, los israelitas, eran autóctonos, indígenas de esa misma tierra.

En 2001 aparece otro libro de Finkelstein, ahora en coautoría con el periodista Neil Asher SILBERMAN, titulado La Biblia desenterrada. Nueva visión arqueológica del Israel Antiguo y de sus textos sagrados (FINKELSTEIN; SILBERNAN, 2001,)9. Esta publicación representa ya, emblemáticamente, la irrupción definitiva del cambio de paradigma: la arqueología se independiza como ciencia, reconoce el excepcional valor documental de la Biblia, aunque no como normativo, y se atreve a presentar su propia visión, radicalmente diferente de la versión de la historia de Israel que la Biblia ofrece.

Esta publicación ha resultado ser mucho más que un éxito editorial, generando un amplio debate, y polémicas, primero entre los especialistas, pero trascendiendo muy pronto a ámbitos académicos y religiosos, incluso a programas

\footnotetext{
${ }^{8}$ Este autor fue uno de los pioneros, con su The Historicity of the Patriarchal Narratives: The Quest for the Historical, 1974.

${ }^{9}$ Versión Inglés de 2001, versión Española de 2003 (Disponible en: <http://www.mercaba.org/Biblia/La\%20Biblia\%20Desenterrada.pdf) bookfi.org>), versión Brasileña “A Bíblia não tinha razão", 2003, y versión Francesa "La Bible dévoilée. Les nouvelles révélations de l'archéologie", 2001.
} 
televisivos de gran divulgación como el canal National Geographic, o el popular Youtube $^{10}$.

Otros autores cuyas obras son consideradas como de referencia en este nuevo paradigma arqueológico-bíblico son: Mario LIVERANI, Thomas L. THOMPSON, Philip R. DAVIES, William DEVER, Keith WHITELAM), etc. ${ }^{11}$

\section{El desafío de la nueva arqueología en síntesis}

Con esta actitud nueva, por la cual la arqueología se ha emancipado y ha dejado de entenderse a sí misma como al servicio de la demostración del relato bíblico, este nuevo paradigma arqueológico nos da una visión muy diferente de la realidad histórica que pueda haber detrás del relato bíblico, en palabras de Finkelstein (CORRADINI, 2006) ${ }^{12}$ :

En dos siglos de investigación científica, la búsqueda de los patriarcas nunca dio resultados positivos. La arqueología ha probado que en esa época no se produjo ningún movimiento masivo de población.

En cuanto al Éxodo, desde el punto de vista científico no resiste el análisis. No existe el menor indicio de su paso por el desierto. [...] Tampoco existieron las grandes batallas mencionadas en los textos sagrados. [...] Los hebreos nunca conquistaron Palestina, porque ya estaban allí. Los primeros israelitas eran pastores nómadas de Canaán que se instalaron en las regiones montañosas en el siglo XII a.C. [...] Tampoco en el caso de la monarquía unificada con David y Salomón la arqueología ha sido capaz de encontrar pruebas del imperio que nos legó la Biblia13: ni en los archivos egipcios ni en el subsuelo palestino. [...] El núcleo del Pentateuco fue concebido quince siglos después de lo que creíamos. Hacia fines del siglo VII a.C. una coalición heteróclita de funcionarios de la corte sería la responsable. (El texto completo de esta entrevista se encuentra al final de este artículo, en el Anexo, p. 373-376).

Esta nueva visión arqueológica no se limita al campo de la Biblia Judía, el Primer Testamento para los cristianos; abarca también al mundo de su Segundo

\footnotetext{
${ }^{10}$ Véase la cantidad de videos sobre Finkelstein, la Biblia desenterrada, el origen del pueblo de Israel... en Youtube, en varios idiomas, y lo muy visionados que han sido.

${ }^{11}$ Cfr la bibliografía final.

${ }^{12} \mathrm{Cfr}$ su entrevista concedida a Luisa CORRADINI, del diario La Nación, Buenos Aires, el 25 de enero de 2006 en la edición impresa.

${ }^{13} \mathrm{Ni}$ David ni Salomón son citados en un solo documento conocido de Egipto ni de Mesopotamia. Cfr. FINKELSTEIN, La Biblia desenterrada, 2001, p. 130.
} 
Testamento. En palabras de Thomas Sheehan ${ }^{14}$ :

Los expertos sobre las Escrituras cristianas dicen que Jesús fue visto por sus contemporáneos como un profeta carismático muy humano, que procuró una reforma del judaísmo de su tiempo. No tuvo intenciones de fundar una nueva religión que le hubiese tenido a él mismo como centro, se hubiera abierto a los gentiles y hubiese sucedido al judaísmo. Mucho menos estuvo preocupado por la sucesión apostólica de los obispos, tan querida a la Iglesia Católica y a la Anglicana. Su predicación se dirigió a los judíos, no a los gentiles, sobre una reinterpretación benigna de la Ley judía y de las tradiciones.

Estos mismos expertos -cristianos o no- afirman que sobre la base de las investigaciones histórico-científicas del Nuevo Testamento, Jesús no se presentó a sí mismo como el Mesías (el Cristo). De hecho, rechazó que le aclamaran como tal. Mucho menos él pensó nunca que fuese Dios, igual a su Padre del cielo, de la forma como el tardío evangelio de Juan (ca. 100 d.C.) lo presenta. Jesús no predicó sobre sí mismo, sino sobre el Reino de Dios, el empoderamiento otorgado por Dios en favor de los menos afortunados: los empobrecidos, los impuros, los social y religiosamente marginados. Llamó a la metanoia -no al arrepentimiento, como es traducida habitualmente la expresión - una conversión radical a una vida de justicia y de misericordia. Jesús se presentó como un judío santo, como los que habría muchos en la Palestina de su tiempo, y como ellos fue también conocido por sus sorprendentes hechos, llamados milagros. A este respecto, el padre John P. Meier, experto católico, después de un exhaustivo análisis de los cuatro evangelios, afirma que sólo once de los treinta y dos milagros atribuidos a Jesús por los evangelistas tienen la posibilidad de responder a un acontecimiento histórico, sin que se trate necesariamente de un acontecimiento milagroso.

Algunos expertos dicen que Jesús esperaba una irrupción cósmica apocalíptica por parte de Dios para establecer su Reino en la tierra. Otros ven a Jesús más como un profeta escatológico ("el tiempo de convertirse es ahora"), no apocalíptico (o sea sin esperar una catástrofe que acabara con el mundo). Apocalíptico o escatológico, el retrato elaborado por estos expertos no encaja en el marco de las doctrinas cristianas sobre Jesús como Segunda Persona de la Trinidad para redimir del pecado a la humanidad. Y más: los expertos actuales, excepto algunos como el obispo anglicano N.T. Wright, no encuentran ninguna evidencia de que la resurrección de Jesús fuese un hecho histórico que tuvo lugar en una determinada tumba cerrada tres días después de su ejecución.

Como se deja ver fácilmente, se trata de un cambio radical frente a la visión tradicional, tenida por indubitablemente histórica, en el campo de la arqueología relacionado con las religiones abrahámicas y con el pueblo de Israel.

${ }^{14}$ Véase el Foreword de Thomas SHEEHAN al libro de John VAN HAGEN, 2012, p. viii-ix. 


\section{La historia que está por detrás de los relatos bíblicos no históricos...}

Pero el desafío que hoy nos hace la nueva arqueología no se reduce a su labor “deconstructiva”. La nueva "arqueología” -tomada ésta en toda la amplitud de su sentido, gracias a su casi inabarcable interdisciplinariedad- no se limita a cuestionar la historicidad fáctica de los textos, sino que trata sobre todo de descubrir, de sacar a la luz el proceso vivo de la creación de los textos bíblicos: quiénes estuvieron detrás de su composición y de su recomposición una y otra vez, en qué circunstancias, con qué propósitos, en qué momentos, tal vez inimaginablemente angustiosos o complejos. Por detrás de los textos aparece toda una historia diferente, más allá de lo que creíamos que era literalmente histórico y que hoy estamos descubierto que no lo es. Por detrás del relato textual bíblico aparece un relato humano diferente, hasta ahora desconocido, y éste sí, muy histórico.

Así, respecto a los escritos básicos de la Biblia Hebrea (del Génesis a los libros de los Reyes), hoy ya creemos saber, parece que casi con plena seguridad, que han sido compuestos en dos momentos peculiares, el del reinado del Rey Josías y el llamado "período persa”, con el retorno de los exiliados de Babilonia.

El Rey Josías (639-609 a.C.) representa el momento de Judá en que ha desaparecido el reino del Norte, que le hacía permanentemente sombra, y es ahora cuando a Judá, que progresa en población, en riqueza y en cultura ${ }^{15}$, se le presenta la posibilidad de extenderse hacia el Norte e incorporar todas las tierras históricas en un solo reino pan-israelita. Es el momento en que Josías y los suyos crean una interpretación global de su historia pasada capaz de trasmitir la utopía de un Israel elegido por Dios y destinado a un futuro de gloria.

En el período persa (538-330 a.C.), tras el exilio, el pueblo está viviendo una postración no sólo física, económica y política, sino sobre todo moral, en la

\footnotetext{
${ }^{15}$ Sólo en este momento, en el siglo VII, y no antes, se puede hablar de una alfabetización difundida hacia el campo desde la capital que permitieran el influjo real de la utilización de las escrituras.
} 
pequeña provincia de Yehud. Se encuentran fracasados, humillados, desorientados. Su Dios no pudo mantener sus promesas, y fue derrotado a manos de un imperio y un dios- más fuertes. Pero aquellas élites religiosas pensantes están tratando de reconciliar sus sueños de pueblo elegido de Yavé con aquella realidad tan frustrante. Con la fuerza creativa de su religiosidad, en medio de unas circunstancias desesperadas, encuentran la oportunidad de rehacer su fe, y lo hacen reenfatizando su identidad como pueblo escogido. Estos judíos ven la mano de Dios en Ciro, enviado por Yahvé para dar una nueva oportunidad a su pueblo. Intuyen que Dios en realidad continúa dando cuenta de la realidad, que no está derrotado, sino que simplemente ha permitido el castigo del pueblo, hasta casi su destrucción total, por causa de sus pecados, para poder restablecerlo con una exhibición de poder. "Presentando a Dios como transcendente y como rector soberano de la historia, estos escritores judíos estaban construyendo el monoteísmo, la fe en un Dios único"16 -hoy parece ya probado que hasta entonces Israel era politeísta ${ }^{17}-$.

Fue durante el período persa cuando estos israelitas llegaron a creer en un dios supranacional, cósmico, señor del Universo. Vinieron a ser monoteístas, creyentes en un Dios que los había destinado a un proyecto grandioso. "Se escribieron a sí mismos dentro de los relatos que crearon, reivindicando ser los sobrevivientes y por tanto los herederos de las promesas: el resto de Israel" (VAN HAGEN, 2012, p. 20).

Muchos arqueólogos no creen hoy día que haya conexión real entre estos judíos del siglo VI en Yehud y los israelitas (o cananeos) del 1200 a.C. Según estos autores "la narración desde Abraham a David es un mito fundacional, como el que Virgilio creó en su Eneida sobre la fundación mítica de Roma por Eneas. Los relatos sobre Abraham, Moisés y David sirvieron para crear la conexión con el Dios

\footnotetext{
${ }^{16}$ Véanse las excelentes reflexiones de VAN HAGEN (2012, p. 19), a quien sigo aquí de cerca.

${ }^{17}$ No sólo parece que antes de esas fechas Israel era politeísta, sino que parece probada la presencia y el culto a Asherá, la esposa de Yavé (DEVER, 2005, p. 252ss). El sancta sanctorum del templo descubierto en el tell de Arad, trasladado al Museo de Israel en Jerusalén, parece demostrarlo clara y concretamente.
} 
de las promesas: ellos eran el pueblo elegido de Dios y aquella era la tierra que Dios les había dado, al margen de lo que pensara el imperio de turno" (VAN HAGEN, 2012, p. 20). La fuerza religiosa de aquel pequeño pueblo, pobre y oprimido, humillado en su propia tierra, les permitió recrearse a sí mismos como el pueblo elegido del Dios único de toda la tierra, destinado a heredar una historia de triunfo y a recibir el reconocimiento futuro de todos los pueblos. Con los relatos bíblicos básicos, creados en este período persa ${ }^{18}$, ocurrió lo contrario de lo que suele ocurrir: los vencidos escribieron la historia, su propia historia, y se inscribieron a sí mismos dentro de una epopeya magnífica por encima de todos los pueblos, de la mano del Dios del monoteísmo radical, redefiniendo su religión y transformando su propia identidad.

Esta "nueva información” que las ciencias histórico-crítico-arqueológicas nos ofrecen hoy socava la historicidad del contenido de las Escrituras, lo cual nos empuja a los creyentes a re-evaluarlas: ¿qué son en realidad las Escrituras? ¿Son palabra de Dios, son palabra nuestra? ¿Qué es realmente lo que nos transmiten, qué significa? ¿Cómo reevaluamos todo a la luz de estas nuevas informaciones?

En la posible decepción que puede comportarnos el descubrimiento de esta creatividad redactora vivida en el llamado período persa -en cuanto que nos pone al descubierto la no historicidad de unos acontecimientos que creíamos históricamente indubitables, testimoniados por unos textos que creíamos bajados del cielo-, podemos descubrir una oportunidad para entender la Biblia de otra manera: no es la obra de Dios, que la envía o la dicta desde el cielo, sino que es la obra del pueblo, de un pueblo que sufre y que en un supremo acto de coraje, se esfuerza por descubrir un nuevo rostro de Dios, recreando la historia y dándose a sí mismo una nueva identidad, capaz de hacerle sobrevivir aun estando sumido en las condiciones más desesperadas. "En esta reconstrucción arqueológico-científica de la historia judía los creyentes podemos percibir un tipo diferente de milagro: el

\footnotetext{
${ }^{18}$ Los profetas (y los textos) anteriores a la Cautividad no conocen a Abraham y en general utilizan el término "padres" para designar a la generación del Éxodo (LIVERANI, 2005, p. 311). Moisés no es citado nunca antes de la Cautividad, y el Sinaí sólo es citado un par de veces (SI 68), y sin relación a la alianza... (LIVERANI, 2005, p. 334).
} 
sentimiento religioso fue el motor que hizo posible la supervivencia y el crecimiento espiritual" (VAN HAGEN, 2012, p. 55). Es decir, fue un "milagro", pero un milagro muy humano; fue la epopeya de coraje de todo un pueblo que se reinventó a sí mismo y recreó su historia con una suprema dignidad. Descubrir esta verdad no nos deja a la intemperie, sino que nos invita a asumir maduramente esta realidad tan humana como sagrada. Si para las personas con una visión muy sobrenaturalista esto puede ser decepcionante, para las personas con una visión más laica y realista resultará un alivio y una esperanza: por fin podemos comprender y acoger los relatos bíblicos sin tener que comulgar con ruedas de molino ni tener que aceptar como literalmente históricos unos relatos en buena

parte míticos. Aparte del mucho material indubitablemente histórico -hoy llamativamente comprobado incluso por fuentes arqueológicas extrabíblicas-, lo que hay de más profundamente histórico en la Biblia, lo que hoy nos resulta más revelador, es el relato existencial-histórico que corre por detrás del relato textual compuesto por los escritores.

\section{La historia que está por detrás del relato cristiano}

Como sabemos, el cristianismo no parte de cero, sino que es una derivación del judaísmo. Por eso, todo el desafío que la nueva arqueología proyecta sobre el judaísmo afecta igualmente al cristianismo, que comparte la misma base o raíz histórica y se considera un Segundo Testamento, una Nueva Alianza, un Nuevo Israel.

En síntesis, el relato cristiano oficial es muy sencillo: anunciado ya por los profetas, Jesús, del linaje de David, ha nacido en el seno del judaísmo, pero es Dios mismo en persona que, en la plenitud de los tiempos, se ha encarnado en este pueblo elegido, para llevar a plenitud la revelación realizada en la Primera Alianza de Dios con su pueblo. Durante los días de su vida pública, este Mesías, Ungido por Dios, ha predicado el mensaje de la salvación, avalándolo con muchos milagros, y ha fundado personalmente la Iglesia, estableciéndola sobre Pedro y los doce 
Apóstoles, a quienes les ha encomendado la guarda y la custodia del depósito de las verdades de la fe. Ejecutado por los romanos, ha resucitado, al tercer día, en cumplimiento de las Escrituras, como lo había predicho, y tras 40 días de aparecerse a sus discípulos ha ascendido al cielo, desde donde ha enviado al Espíritu Santo en Pentecostés, que cuida por la atención y el crecimiento de la Iglesia, Iglesia que goza de la promesa de que las puertas del infierno no prevalecerán contra ella, hasta el final de los tiempos.

Éste relato básico concerniente a Jesús ha llegado hasta nosotros y ha sido creído y tenido como absolutamente histórico desde hace unos dos mil años. Otro relato básico cristiano -de otra naturaleza pero "relato" al fin y al cabo- podemos identificarlo en el credo niceno-constantinopolitano, que también ha sido proclamado siempre como histórico. No hace falta recordar que los relatos bíblicos de la Biblia Judía, el Primer Testamento, han formado parte del patrimonio simbólico cristiano, e igual que en el judaísmo han sido tenidos sostenida e indubitablemente como históricos ${ }^{19}$.

Es sabido cómo la reconstrucción del "Jesús histórico" es una empresa tal vez imposible. A pesar de ello, hoy sabemos muchas cosas del Jesús real, y las sabemos con una certeza mucho más fundamentada que la seguridad ingenua con la que secularmente nuestros mayores han creído como literalmente histórico el relato tradicional sobre Jesús (tanto el de los evangelios como el oficial más amplio construido por la Iglesia).

Pues bien, así como es casi imposible reconstruir con toda seguridad el "Jesús histórico", también lo es reconstruir con seguridad la "Iglesia histórica”, la

\footnotetext{
${ }^{19}$ De apenas hace poco más de un siglo es la última intervención conminatoria de la Pontificia Comisión Bíblica, en 1906, insistiendo oficialmente en el carácter histórico de los relatos de los 11 primeros capítulos del Génesis. Pero todavía en 2008, el Cardenal Bertone, ante el estupor general de los biblistas del mundo entero, retiró las licencias docentes y ministeriales al biblista argentino Ariel Álvarez Valdés por no aceptar la retractación que le imponía mandándole reconocer que los primeros capítulos del Génesis son históricos, que los milagros existen y que en ellos Dios suspende las leyes naturales, que el diálogo de María con el ángel en la anunciación es un diálogo histórico y real, que al morir una persona se separa el alma del cuerpo y va al encuentro de Dios, que María se aparece físicamente a quienes la ven... y otras varias reivindicaciones de historicidad bíblica semejantes. Bertone, entonces secretario de Estado Vaticano, había sido durante años secretario de la Congregación para la Doctrina de la Fe y brazo derecho de Josef Ratzinger en la misma.
} 
historia concreta del surgimiento del cristianismo. Durante los últimos siglos se ha realizado una cantidad inmensa de investigaciones y hallazgos al respecto, y recientemente, la nueva "arqueología" 20 -también en este campo del Jesús histórico y de la Iglesia histórica- ha llegado a descubrimientos que constituyen un cambio radical de paradigma, frente a la ingenua aceptación tradicional de la historicidad de aquellos relatos sobre Jesús y sobre la Iglesia. El nuevo paradigma nos sugiere que las cosas no son como creíamos, sino muy diferentes. Veamos.

A partir de muchas fuentes histórico-arqueológicas, hoy es dado por históricamente cierto que Jesús no fundó la Iglesia ni pensó nunca en iniciar una nueva religión. Fue siempre un judío piadoso y se dirigió siempre al pueblo judío. Nunca dijo de sí mismo las afirmaciones tremendas que Juan evangelista pone en su boca, y con la misma probabilidad, nunca las pensó siquiera. Fue un judío piadoso celoso por la renovación de la fe judía, ejecutado finalmente por el poder romano en una crucifixión que no tuvo nada de inusual en aquel país sojuzgado por el poder imperial.

A los pocos años de su muerte, entre 10 y 20 años después, sólo encontramos rastros de su memoria en dos grupos. Uno, en su propia tierra galilea. Son grupos, comunidades judías, reunidas en torno a los discípulos y a los "hermanos de Jesús". No son un nuevo grupo, ni una nueva secta judía, sino sólo lo que pudiéramos llamar un movimiento embrionario de renovación espiritual dentro de la religión judía. Las exhortaciones de Jesús al amor, a la misericordia, son su estribillo. El sermón de la montaña es su referencia. Son un retoño de la espiritualidad de Jesús, reconocido sobre todo como el profeta galileo. Podemos entrever algunos vestigios de su presencia a través del Evangelio de Marcos, y lo que será la fuente Q. Profesan un evangelio sin concepción virginal y sin Navidad, sin última cena ni pasión ni resurrección, sin Cristo mediador entre Dios y los seres humanos, sin muerte expiatoria ni señorío de Cristo. Esta comunidad o grupo de comunidades galileas son los primogénitos de la Iglesia. Su espiritualidad quedará

\footnotetext{
${ }^{20}$ En el citado sentido más interdisciplinar y amplio.
} 
más tarde eclipsada por las cartas de Pablo y los textos de Juan, pero antes de desaparecer dejarán un valioso documento, la fuente Q (MYRE, 2011, p. 15-34). Son el primer paso del movimiento de Jesús²1, el “eslabón perdido” entre Jesús y los que llamaremos primeros cristianos ${ }^{22}$.

Por su parte, tras la muerte de Jesús, aparece en Jerusalén otras comunidades, dirigidas por Santiago el menor, hermano de Jesús, que observan las prescripciones judías y rezan en el Templo, pero celebran semanalmente una cena en memoria de Jesús, lo creen resucitado y esperan vivamente su vuelta como Mesías del Reino. Jesús es para ellos ante todo el Mesías. Son y se sienten judíos, plenamente judíos. De hecho, consideran que son el verdadero Israel, el judaísmo auténtico, y que las promesas hechas a Israel se han cumplido en Jesús. Esto comienza a suscitar tensión frente a las autoridades judías, que comienzan a perseguirles y a excomulgarles, lo que provoca su dispersión. Con el martirio de Santiago, la caída de Jerusalén y la destrucción del Templo en el año 70 d.C., estas comunidades parece que terminan por desaparecer al comienzo del siglo segundo 23 .

Pero la memoria de Jesús sobrevivirá a pesar de todo gracias al éxito del judaísmo helenista de la diáspora. Allí la comunidad "cristiana” se compone de judíos helenizantes convertidos a Jesús, personas "temerosas de Dios" y "prosélitos" de Judea y de toda la diáspora. La espiritualidad de estas comunidades tiene varias características fundamentales: el énfasis recae en el amor al prójimo; surge el amor a Cristo en cuanto Crucificado-Resucitado que ejerce su señorío sobre los creyentes, que se arrodillan ante él; habiendo partido Jesús, es el Espíritu quien asume el protagonismo, y Jesús pasa a ser el centro de la predicación, como Hijo de Dios; en un momento de gran efervescencia apocalíptica, la convicción de que el final del mundo está próximo sufrirá un proceso de anticipación y de

\footnotetext{
${ }^{21}$ THEISSEN (1979) es quizá quien más ha investigado y escrito sobre el movimiento de Jesús.

${ }^{22}$ Me estoy valiendo en esta síntesis de la obra de BERGERON (2004), a quien sigo de cerca. Utilizo la edición brasileña: Fora da Igreja também há salvação, 2009, p. 33ss.

${ }^{23}$ Tal vez están en el origen de los ebionitas, la secta ascética que rechazaba las cartas de Pablo y se valía solamente del evangelio de Mateo.
} 
interiorización en una escatología vivida ahora en el presente, en lo íntimo del alma. En el transcurso del siglo I el cristianismo pasó por estas tres etapas, con una forma concreta de considerar a Jesús en cada una de ellas: como profeta, en la comunidad galilea, como Cristo en la comunidad jerosolimitana, y como Hijo de Dios en el judaísmo helenista.

Muchos discípulos de Jesús judíos seguían considerando a Jerusalén y el Templo no sólo como el único lugar de culto, sino como el lugar en el que se realizarían las promesas de Dios, al que Jesús mismo retornaría glorioso para cumplir las escrituras judías. En ese contexto podemos imaginar la tragedia que tuvo que significar la destrucción del Templo y de Jerusalén en el año 70 d.C. No fue un desastre sólo político o económico, sino religioso, porque la piedra de toque de las promesas de Dios era la absoluta centralidad de la ciudad santa y su Templo, el lugar más sagrado de la tierra, desde el que Dios gobernaría su Reino en este mundo. Los seguidores judíos de Jesús, que todavía no conocían la doctrina de la Trinidad, ni que la Segunda Persona se hizo hombre por el poder del Espíritu, ni que Jesús resucitó (sino que fue despertado por Dios), ni pensaban en ninguna Iglesia, dispersos por las comunidades en torno a Jerusalén, fueron elaborando y coleccionando relatos sobre Jesús, cuando todavía no habían sido escritos los evangelios. No tejieron tanto una biografía de Jesús, cuanto reivindicaron que a pesar del desastre, Dios mantenía su plan de cumplir sus promesas. Jesús revelaba un nuevo capítulo de ese plan de Dios, y ellos eran ahora un Nuevo Israel, la continuación o los sucesores de la religión de la que provenían, mientras continuaban utilizando las Escrituras judías, ahora recontextualizadas con una nueva significación. Sin autoridad central, las diversas comunidades realizaron un fantástico esfuerzo a la búsqueda de su propia identidad: quiénes eran ellas en el plan de Dios, qué significaba todo aquello (VAN HAGEN, 2012, p. 10oss).

Por su parte, en aquella difícil situación, judíos no seguidores de Jesús, reconstruyeron en torno a Jamnia (ca. 80-90 d.C., al Norte de Jerusalén, una nueva versión de la religión judía, centrada principalmente en el cultivo de las 
Escrituras, sobre todo en la línea de la tradición farisea. Sin Templo ni sacerdocio, pusieron el acento en los ritos cultuales domésticos. Uno y otro grupo, los judeocristianos por una parte, y los judíos organizados en torno a Jamnia acabarán distanciándose y separándose (VIDAL MANZANARES, 1995, p. 191ss).

La "nueva arqueología” -en sentido amplio- de la que hablamos ha puesto al descubierto la enorme complejidad de este itinerario del nacimiento del cristianismo. Un momento inicial de este cambio de paradigma se dio en 1940, con el descubrimiento arqueológico de los documentos de Nag Hammadi. La tradicional visión de un único cristianismo, que procedería uniformemente desde Jesús, quedó seriamente contradicha. Multitud de estudios arqueológicos han llamado la atención sobre la ingente cantidad de literatura cristiana temprana y las muchas comunidades que la produjeron. En 2003, Bart EHRMAN publicó dos libros, Cristianismos perdidos (EHRMAN, 2003a), y Lost Scriptures (EHRMAN, 2003b), que mostraron la tremenda variedad de lo que podríamos llamar cristianismos primitivos. En 1984, Raymond BROWN argumentó contra la idealizada visión de un cristianismo fundado por Jesús y dirigido por los apóstoles, mostrando que las diferentes comunidades tenían diferente organización y diverso pensamiento doctrinal. John Dominic CROSSAN subrayó el conflicto entre los predicadores ambulantes del primer siglo y los conservadores animadores de las comunidades domésticas. Detrás de la idealizada visión del relato del libro de los Hechos de los Apóstoles, ha sido desenterrada también toda una historia densa, compleja... en la que descubrimos que están actuantes, como no podría ser de otra manera, las angustias y las esperanzas, los conflictos y la pasión religiosa de aquellas comunidades, siempre en diálogo con la cultura y la religiosidad de las demás formaciones religiosas y filosóficas circundantes. Es, como venimos diciendo, "el relato que está por detrás del relato”, el relato existencial-histórico que da su verdadero sentido al relato textual superficial, y hoy los nuevos descubrimientos histórico-arqueológicos nos invitan a profundizar también nosotros en la percepción de este sentido. 
Ese complejo itinerario -que ahora no vamos a continuar recorriendo aquípasa luego por el encuentro del pagano-cristianismo (helénico, ya separado del judaísmo) con el mundo de la filosofía greco-latina, que lejos de ser un simple acerbo racional de conocimientos, era toda una forma de sabiduría religiosa, con la que el cristianismo entró en diálogo y en comunión, durante un período muy fecundo de transformación. Y luego, más tarde, fue el encuentro con la religio romana, cuando la presencia creciente del cristianismo en el imperio romano, y la también creciente debilidad de éste, propician un diálogo entre ambos, que resultó ser más que diálogo: una sustitución, por la que el cristianismo asumió el papel de religión de Estado del imperio y se convirtió -ahora sí- en una "religión", ya a partir del siglo IV d.C.

Esta descripción sumaria que acabamos de hacer del itinerario que va desde Jesús hasta la llamada "religión cristiana" que dice fundarse en Jesús, sólo ha pretendido aludir aquí, sin demasiado rigor ni exhaustividad, a todo un mundo de nueva información que la nueva arqueología ha sacado a la luz y que continúa cada día desvelando. Afortunadamente, mucha de esta información está puesta al alcance del lector medio, y su lectura y estudio no puede menos de ser recomendada. Si esta pequeña y superficial descripción invita al acceso directo, habrá cumplido uno de sus objetivos.

\section{Intermezzo: ¿Cuál es la "novedad" de este "nuevo" paradigma arqueológico bíblico?}

Toda esta nueva información de la "nueva arqueología" no es tan nueva: ya se venía diciendo hace varias décadas. En 1987 salió un primer libro (MILLER; HAYES, 1986) que partía declaradamente del supuesto de que los patriarcas y el éxodo no eran históricos. En 1974, Thompson ya había aventurado en solitario esa posibilidad. Todos los biblistas y cristianos formados bíblicamente hace más de treinta años ya han escuchado estas posiciones hace tiempo, aunque más bien como una hipótesis académica plausible, no como la posición adquirida de consenso "científico" y mayoritario. (Los que no las conocían son la mayor parte de 
los cristianos de base, porque no quisimos asustarlos con lo que parecían sólo hipótesis académicas extremistas que podían destruir la fe...).

Lo "nuevo" no es el grueso del contenido de las afirmaciones que hoy nos ofrece la nueva arqueología sino

- su estatuto epistemológico (hoy es un dato globalizado y demostrado, no simplemente de detalle y sospechado),

- y el acceso que estamos teniendo al "relato detrás del relato".

Ambas novedades exigen, por coherencia, una nueva actitud, a saber:

- No continuar prolongando sin más la misma reflexión teológica o teológico-bíblica que fue elaborada cuando teníamos por históricos los eventos bíblicos fundamentales (Abraham, patriarcas, alianza, éxodo, conquista, monarquía unida, promesas...) que hoy sabemos que no lo son; el estado actual de los conocimientos tiene que ser asumido con toda claridad y explicitud en una teología y en una fe responsables. La mayor parte de lo que la teología bíblica actual sigue diciendo, es lo mismo que lo que se decía cuando pensábamos que todo era histórico y afirmábamos que si no lo fuese no sería posible nuestra fe; con ello continuamos siendo deudores de paradigmas anacrónicos, que no pueden sino hacer imposible una vivencia religiosa integralmente actualizada.

- Es urgente elaborar una teología y una forma de creer que asuma explícitamente estos hallazgos históricos; tal vez porque carecemos de ella es por lo que mucha gente abandona la fe. Continuar con las viejas teologías es una irresponsabilidad pastoral para con los sectores más conscientes de la moderna sociedad culta, que ya no aguantan una epistemología mítica que da la espalda a la historia real.

El "relato tras el relato" al que estamos accediendo, conlleva el desafío de reconceptuar la religión: ya no es aceptable el paradigma de una "historia de 
salvación", ni de responder/creer a un Dios que ha intervenido en la historia manifestándose/pidiéndonos una respuesta de fe. Estas metáforas quedan superadas a la luz de los conocimientos actuales, y en el contexto de una sociedad científicamente informada comienzan a resultar no sólo anacrónicas, sino perjudiciales, pues lastran la religión atándola a una época cognitiva que está destinada a morir. Antropológicamente, se hace necesaria una "desobjetivización" de la vivencia religiosa, de la Palabra de Dios, de la institucionalización religiosa... así como la necesidad de ir creando una práctica religiosa coherente con este nuevo paradigma.

Si una persona no capta toda esta "novedad", probablemente ello significa que está instalada en un tipo de fe para el que resulta irrelevante que aquello en lo que se cree sea un acontecimiento histórico de intervención de Dios o sea una construcción humana; en una posición mental semejante, sí, efectivamente, el nuevo paradigma arqueológico-bíblico no aportaría novedad significativa alguna y resultaría irrelevante. Pero esperamos que no sea el caso de nuestros lectores.

\section{Lo que está en juego}

Esta nueva visión que deriva de la nueva visión arqueológico-bíblica desplaza a otra, la tradicional, sobre la que había muchos valores en juego. Aludamos a ellos aunque sea brevemente.

\section{a) Para Israel (Estado, pueblo de Israel y religión judía)}

- Está en juego en primer lugar la identidad del pueblo de Israel. La tradición bíblica, ha consistido en la creencia, tenida por histórica, de que Israel es un pueblo diferente, venido de fuera de Palestina, diferente de los cananeos -el pueblo autóctono-, creado por Dios a partir de la elección de Abraham y la Alianza que selló con él y su descendencia. Israel sería la descendencia biológica de aquellos patriarcas ancestrales, del pueblo judío oprimido en Egipto, que luego del éxodo y de la peregrinación por el desierto, conquistó la tierra de Canaán que Dios 
había prometido a Abraham. Si los patriarcas son sólo una figuración religiosa, si el pueblo judío no estuvo en Egipto, ni tuvo lugar el éxodo, ni la peregrinación por el desierto... ni por tanto Moisés, ni la Pascua, ni la Alianza del Sinaí... ¿qué queda de la identidad de Israel? ¿Qué es el pueblo de Israel?

- Está en juego el derecho del pueblo y del Estado de Israel a la tierra que está ocupando. En el Parlamento de Israel se sigue invocando todavía hoy la Biblia para fundamentar el derecho de Israel a la tierra, apelando además concretamente a la circunscripción de los límites de Israel que en la Biblia aparecen, como límites de la tierra que Dios mismo dio a su pueblo. Si no hubo pueblo israelita venido de fuera de Palestina, si no hubo conquista por la que Dios les entregara esa tierra, si los cananeos no fueron exterminados ni eran un pueblo diferente, ¿qué derechos tiene Israel a la tierra de Palestina, que no tengan otros pueblos que también han morado multisecularmente en ella?

- Si los relatos bíblicos que contienen esa saga supuestamente histórica del pueblo de Israel, son una creación literaria religiosa, ¿en qué consiste la identidad étnico-cultural del pueblo de Israel? Existe todo un debate al respecto sobre el carácter "inventado" (construido) de la identidad de Israel; la posición emblemática es la de Shlomo SAND (2008), profesor de historia de la Universidad de Tel Aviv24.

- Fuera de Israel, en Occidente, son muchas las entidades para las que Israel juega un papel simbólico. Pensemos por ejemplo, en Estados Unidos, cuya identidad nacional está ligada al Destino Manifiesto de ser un Nuevo Israel, puesto por Dios al servicio de la humanidad, para difundir los valores de la libertad y la democracia, "como ciudad que se alza sobre la colina", luz para los pueblos. La nueva perspectiva arqueológica sobre la historicidad de sus orígenes, sin duda, aconsejará una reconsideración de esta conciencia identitaria.

\footnotetext{
${ }^{24}$ Cfr su libro Comment le peuple juif fut inventé, 2008 (traducción española, 2011; traducción al inglés, 2009). El libro es el primero de una trilogía; el segundo volumen es La invención del pueblo de Israel, 2011 (The Invention of the Land of Israel, 2012; English translation by Verso, 2012). Y el tercero será La invención del judío secular. Existe un video de la presentación pública del segundo libro en Londres (http://youtu.be/sqj_UOdHxpk).
} 


\section{b) Para las religiones abrahámicas}

Son tres las religiones que se remiten a Abraham y a toda la historia que la Biblia relata sobre él y su descendencia. Todo ese patrimonio religioso escriturístico es puesto en cuestión por la nueva arqueología. Autores muy serios hablan de "invención" 25. Los descubrimientos histórico-arqueológicos obligan a replantearse la historicidad de la Biblia, y como consecuencia de ello, es necesario igualmente un replanteamiento de su significado ${ }^{26}$.

\section{c) Para el cristianismo}

Como religión abrahámica, el cristianismo se siente desafiado, en cuanto que debe reconsiderar toda la historiografía bíblica veterotestamentaria sobre la que se apoya, pues se considera heredero sustituto de la promesa hecha en primer lugar a Israel.

Lo que actualmente hemos venido a saber sobre Jesús y sobre los textos y tradiciones fundamentales y fundantes del cristianismo, presenta también una visión radicalmente diferente de la que ha sido su relato oficial durante casi dos mil años. Esta nueva visión histórica de Jesús y de la gestación de los textos cristianos fundacionales, presenta, estructuralmente, el mismo desafío que el nuevo paradigma arqueológico-bíblico presenta al mundo del Antiguo Testamento.

Si es cierta la nueva visión arqueológico-histórica sobre Jesús y sobre la redacción del Nuevo Testamento, entonces todo necesita ser reelaborado, porque el relato tradicional se ha basado en creencias míticas hoy demostradamente inciertas. Si Jesús no quiso fundar una Iglesia, si nunca pensó abandonar el

\footnotetext{
${ }^{25}$ La segunda parte del libro de LIVERANI (2005), Más allá de la Biblia, se titula “Una historia inventada”, y se subdivide en seis capítulos sobre "La invención de" los patriarcas, de la conquista, de los jueces, del reino unido, del templo salomónico y de la Ley.

${ }^{26}$ "Actualmente el conocimiento del Antiguo Testamento está en plena mutación. No ha cesado de estar en cuestión desde los comienzos de la exégesis científica, digamos ya desde el siglo XVI, pero más todavía desde los descubrimientos arqueológicos del último siglo... Obras muy recientes han puesto en cuestión el conjunto de la historiografía bíblica, y autores muy serios hablan abiertamente de la invención de la Biblia, incluso del pueblo judío. Se sabe que todo el Pentateuco ha sido inventado en los siglos VI y V antes de nuestra era, y toda la historia de los patriarcas y la salida de Egipto y de la entrada en Canaán son reenviadas al mundo de la leyenda" (MOINGT, 2010, p. 96-97).
} 
judaísmo, si nunca pensó de sí mismo lo que hasta ahora habíamos pensado que pensó, si mucho de lo que pensábamos que dijo y que hizo no es así como fue... se hace imperativo afrontar esta disonancia cognitiva con la que nos confronta el nuevo paradigma arqueológico-bíblico, y recrear el conjunto; la visión anterior ya no sirve para los hombres y mujeres informados de hoy.

\section{d) Para la antropología y la teología de la religión}

Para la visión occidental al menos, a partir de la experiencia de los tres monoteísmos, la religión ha sido clásicamente considerada como dotada de una entidad espiritual que derivaba directamente de unos eventos históricos que constituían una intervención fundadora de Dios en la historia. Desde "siempre" ha pensado así la humanidad, tal vez en la mayor parte de las religiones. Toda religión provenía originalmente de una mano tendida por Dios a la humanidad; nuestra religiosidad era respuesta a Dios que había intervenido en la historia. Esta intervención era la base sobre la que todo lo demás se apoyaba. Y aun cuando esa intervención quedaba muy lejos en el tiempo, esta misma lejanía la protegía, al hacerla inatacable: nadie podía probar lo contrario, mientras que bastaba la fe para creer en ella.

El nuevo paradigma arqueológico-bíblico cambia esta situación, que había permanecido estable desde tiempos inmemoriales, ancestrales. Hoy, la arqueología sí tiene medios para remontarse hacia atrás y darnos cuenta crítica de aquella supuesta intervención "histórica" de Dios sobre la que se funda cada religión. Sí puede decirnos si aquel relato religioso es o puede ser realmente histórico, o si es construcción humana. Y este cambio de status, obviamente, lo cambia todo, y exige elaborar una nueva autocomprensión de nosotros mismos como adherentes a una religión.

La pregunta es: si hasta ahora, desde siempre, la religión era una respuesta humana al Dios que había salido a nuestro encuentro en la historia real, ¿̇cómo 
reentender la religión cuando sabemos por la ciencia (la nueva arqueología entre otras) que la mayor parte de aquella salida de Dios a nuestro encuentro fue una elaboración religiosa, una creencia expresada en unos mitos geniales, una construcción nuestra? ¿Cómo ser religioso asumiendo estos nuevos datos?

\section{Pistas para reflexionar}

Este nuevo paradigma arqueológico-bíblico es muy reciente, está apenas en su etapa de divulgación. Todavía no ha sido acogido en la reflexión teológica. Su desafío es enorme. Como hemos dicho, obliga a replantearse radicalmente la entidad y el significado de la religión: a esta nueva luz, ser religiosos parece que es otra cosa que lo que estuvimos siempre pensando. Aquí nosotros sólo queremos sugerir/plantear varios caminos de reflexión cuya necesidad y urgencia parecen claras.

\subsection{Estamos ante un nuevo episodio del viejo conflicto fe/ciencia}

En su discurso en el acto de erección de la estatua a Galileo en los jardines vaticanos en 1992, dijo Juan Pablo II que el conflicto entre fe y ciencia había terminado. Pero no era cierto: el conflicto había acabado con la astrofísica, pero continúa con otras ciencias: la antropología, la epistemología, la cosmo-biología... están hoy en conflicto con la fe, en cuanto ciencias. Con el abandono del paradigma de la vieja "arqueología bíblica" es la nueva arqueología la que ha entrado también en conflicto con la fe. Es decir, como en el caso de la astrofísica con Galileo, es ahora la nueva arqueología la que aporta una "nueva información", que choca con informaciones hasta ahora incluidas oficialmente en el paquete de nuestra fe. Tomábamos a Abraham, la alianza, los patriarcas, el éxodo, la conquista de la tierra prometida, las promesas a David... como ciertos históricamente, como intervenciones históricas de Dios mismo en las que se apoyaba directa e 
indubitablemente nuestra fe $\mathrm{f}^{27}$. Y ahora la nueva arqueología nos dice que las cosas no fueron como pensábamos, que la información sobre la que apoyábamos "nuestra respuesta a la intervención de Dios” no es cierta. Pero no sólo eso: también nos informa de muchos pormenores que nos ayudan a entender qué es lo que realmente pasó, de qué se trataba realmente, si no era sin más una intervención histórica de Dios.

En realidad, no estamos ante nada radicalmente nuevo: se trata de un nuevo episodio, uno más, del casi permanente conflicto fe-ciencia. Conforme ha surgido la ciencia moderna, hace unos pocos siglos, la ampliación que ésta ha ido haciendo del conocimiento ha entrado en zonas que la conciencia humana religiosa había rellenado simplemente como pudo, normalmente con creencias elaboradas por nosotros mismos mediante una epistemología mítica ${ }^{28}$. Casi todos los grandes avances científicos han provocado reajustes que la conciencia religiosa ha tenido que hacer, al estar ésta construida sobre supuestos (míticos, creenciales, acríticos) que las "nuevas informaciones" aportadas por las ciencias, han contradicho"2. Ahora ha tomado la vez la arqueología, cuando con sus muchos nuevos procedimientos y tecnologías ha adquirido una potencia capaz de "desenterrar la Biblia"3o... Y tal como en el caso del heliocentrismo la religión tuvo que aceptar el desafío y abandonar su geocentrismo, por más que se sintiera en él como en su propia casa, ahora la religión va a tener que abandonar la visión clásica de "la intervención histórica de Dios que nos pide una respuesta de fe", lo que ha sido hasta ahora la "fórmula dimensional", el ADN de la vivencia religiosa.

\footnotetext{
${ }^{27}$ La Palestine Exploration Fund, en los orígenes mismos de la arqueología bíblica, fue fundada precisamente para demostrar la veracidad de la Biblia. Uno de los primeros libros que patrocinó la Fundación se tituló: “The Bible is true!” (MARSTON, 1934, título. Cfr. también: BRIEND, ARTUS, NOËL, 2006, p. 2). Por eso también el titulo del emblemático libro Y la Biblia tenía razón, de Werner Keller (1956), ya en el siglo XX. Al respecto, es significativo que la edición brasileña del libro de Finkelstein (2003), La Biblia desenterrada, se tomó la libertad de modificar el título, publicándolo como Y la Biblia no tenía razón (en la editorial A Jirafa).

${ }^{28}$ Utilizo la palabra, como el concepto de mito, en un sentido plenamente positivo, hoy muy revalorizado en la antropología cultural.

${ }^{29}$ Por ejemplo, seguir utilizando hoy, como referencias básicas, categorías bíblicas míticas (creación de las especies en su situación actual, creación especial de nuestra especie en el sexto día, Adán y Eva, estado preternatural, pecado original...) y no incorporar plenamente los descubrimientos científicos que la "arquelogía" biológica y paleontológica actual "desentierran", puede resultar no sólo anacrónico, sino sobre todo dañino, al perpetuar el divorcio fe/ciencia. Una catequesis sobre el origen de la naturaleza humana a partir del Génesis no podría hacerse hoy responsablemente sin combinarlo, por ejemplo, con el actual bestseller de Yuval Noah HARARI: Sapiens: a brief history of humankind, 2014. (en español: Breve historia de la Humanidad, 2014).

${ }^{30}$ Aludo al título del libro emblemático de Finkelstein (2003), La Biblia desenterrada.
} 
La religión necesita una nueva autocomprensión, para un futuro diferente, porque necesita reinventarse. Reinvención que no tendría que generar desconfianza, pues estamos descubriendo con gozo que tanto las religiones agrarias como el acceso mismo a la dimensión espiritual fueron una geniales invenciones creativas "emergentes" ${ }^{1}$ en el proceso biocultural de nuestra hominización y humanización.

\section{2 ¿Una nueva teología de la religión?}

Aun a sabiendas de la inexistencia de una definición de religión que sea comúnmente admitida, podríamos asumir provisionalmente que las religiones del libro se han considerado a sí mismas, de alguna manera, como la relación de los seres humanos con Dios, establecida en respuesta a su intervención en la historia, en una serie de acciones y manifestaciones cuyo relato revelado se conserva en la Escritura. Este tipo de religiosidad ha sido vivida con gran conciencia de objetividad y de historicidad, como la realidad más real, sagrada y decisiva. Así ha sido durante milenios. Esta forma de religiosidad encajaba bien en las posibilidades cognitivas y funcionales de nuestra especie: ha funcionado sin dificultades, haciéndonos viables y siendo, con su poderosa fuerza evocadora de sentido, un gran medio de sobrevivencia.

Pero hoy estamos en un momento de transformación evolutiva, causado principalmente -aunque no únicamente- por una ampliación incesante del conocimiento en todas sus campos y dimensiones: científica, crítica, reflexiva, retrospectiva, cósmica... Y uno de sus efectos sorprendentes es el de poner incluso a nuestro alcance el conocimiento del pasado del que provenimos. A partir de un cierto momento de inflexión, ahora, cuanto más avanzamos, más retrocedemos en el tiempo, más recuperamos el pasado de la sociedad, de la religión, de la Tierra y

\footnotetext{
${ }^{31}$ La hipótesis científica "emergentista" ha dejado atrás el reduccionismo y el materialismo decimonónicos de la ciencia tradicional, que nos empujaban a los creyentes a agarrarnos a posturas filosóficas dualistas y espiritualistas inspiradas en el pensamiento platónico y aristotélico. Una nueva relación entre materia, vida y espiritualidad preside la actual visión compartida entre fe y ciencia: la historia de la evolución de los sistemas vivientes está marcada por la continua "emergencia" de formas, facultades y niveles nuevos. (ANDERSON, More Is Different, 1972, p. 393-396; NÚÑEZ DE CASTRO, Emergencia, vida y autotranscendencia activa, en BERMEJO, 2014, p. 169-212).
} 
del cosmos incluso. No sólo el pasado de la cultura material, sino también de la cultura también ideológica y espiritual. Hoy tenemos tecnologías capaces de "leer" la documentación histórica que está escrita de mil formas en las rocas, en el suelo, en el subsuelo, en las huellas arqueológicas... pero también en los textos y sus contextos, en las ideas y en su evolución...

Es aquí donde se enmarca el desafío de la nueva “arqueología”, que nos golpea con su constatación de que el relato religioso básico de las religiones del libro, que considerábamos básicamente histórico-objetivo, no lo es. Lo realmente histórico es "otro relato", oculto hasta ahora, que nos habla de una gesta de creatividad espiritual de pueblos que, mediante su experiencia religiosa, encontraron fuerzas para sobreponerse a situaciones desesperadas, prácticamente asediados por la muerte, y fueron capaces de dotarse de un nuevo sentido, y de sobrevivir, con el recurso de su propia religiosidad. Apoyada en la seguridad de la intervención histórica de Dios en el pasado y en el futuro por venir, aquellos pueblos o comunidades hicieron de necesidad virtud, y encontraron fuerzas para reinventarse y sobrevivir.

Hoy sabemos que esto último es lo realmente histórico, la verdad profunda del relato bíblico. Los relatos religiosos mismos hoy los sabemos no históricos ${ }^{2}$. A estas alturas del desarrollo de la ciencia hemos perdido la capacidad de ingenuidad mítico/histórica. Por efecto del contexto cognitivo-cultural en el que nos movemos, nuestra especie está cambiando, en cuanto que las actuales generaciones se están volviendo incapaces de funcionar con epistemología mítica, ya no pueden “creer” (porque "saben") en intervenciones objetivas de Dios en la historia, ni son capaces de volver a creer en "grandes relatos" totalizantes que unan cielo y tierra, la creación con la escatología... Seguimos necesitando un sentido para la vida, pero ya no somos capaces de echar mano de "grandes relatos" para construirlo. Hoy somos

\footnotetext{
${ }^{32} \mathrm{Ni}$ son relatos literalmente históricos, ni las Escrituras son el relato objetivo de una intervención de Dios en la historia, ni la historia es su significado principal, todo lo cual no quita que muchos de sus datos y relatos concretos tengan base histórica.
} 
de otra manera. Una religión basada en aquel tipo de instrumentos cognoscitivoepistemológicos empieza a no sernos ya posible.

La humanidad está atravesando una crisis múltiple, y a ella se añade esta crisis del despojamiento de aquellas seguridades supuestamente objetivas, históricas. Como nuestros antecesores, estamos llamados a sobreponernos y a sobrevivir, a reconstruir nuestras esperanzas y nuestro sentido para vivir, pero ha de ser sobre nuevas bases, mediante otros mecanismos cognoscitivoepistemológicos.

Hemos de hacer lo mismo que hicieron ellos: vivir, recrear la posibilidad y la potencia de la vida, pero ahora habrá de ser en el nuevo nicho epistemológico al que estamos accediendo. Lo nuestro será también una vivencia espiritual, como la de ellos, pero se jugará en otro campo, con otros interlocutores y contextos. Tal vez es el momento en que nuestra espiritualidad se está viendo forzada a madurar (haciendo también de necesidad virtud) hasta llegar a saber vivir sin "grandes relatos”, sin cosmogonías ni mitos fundacionales, sin doctrinas reveladas, sin verdades dogmáticas, o simplemente "sin verdades"... simplemente en conexión con el espíritu y la fuerza de la Vida misma, telúrica y cósmicamente percibida y hecha nuestra.

Cada vez distinguimos más y mejor la vivencia espiritual, frente a las representaciones, mitos, relatos, categorías, gestos, doctrinas y rituales con los que la expresamos. La vivencia espiritual es profundidad humana, vivencia humana profunda. Las representaciones, categorías, relatos, ritos... son simplemente los medios de los que nuestra especie se ha valido en un determinado estadio de su desarrollo para expresar, percibir, sentir, comunicar esa vivencia. La vivencia espiritual es una realidad humana permanente; sus representaciones son aleatorias, contingentes, variables según las coordenadas espacio-temporales y culturales. 
No obstante, estamos apenas en el tránsito (ARNOLD, 2015), en el transcurso de esta transformación. Muchas personas no van a poder entrar por este nuevo camino, pues preferirán continuar instaladas en la religiosidad objetivista. No es fácil cambiar de paradigma religioso, es como volver a nacer, entrar en un mundo diferente. Pero otras muchas personas hace tiempo que se están desligando del viejo paradigma; sienten que aquella forma de ser religiosos ya no es viable; se sienten incómodos en ella y hasta dudan de su legitimidad... Por eso acogen con alivio la noticia del nuevo paradigma no objetivista: se puede ser plenamente humano, espiritual por tanto, con los pies firmemente en el suelo del mundo cognitivo que la ciencia actual nos posibilita. En este sentido, el nuevo paradigma arqueológico bíblico nos ayuda a crecer evolutivamente.

Con ello, este paradigma religioso al que la nueva arqueología nos impulsa converge con el paradigma pos-religional33. Ambos reclaman un nuevo modo de habérnoslas con el tradicional concepto de religión. Es urgente una reconceptuación de la misma, así como una nueva teología de lo religioso y de lo espiritual. Manos a la obra.

\section{3 ¿Una nueva teología de la Revelación?}

Hoy que la nueva arqueología desafía la historicidad de la Biblia, el pensamiento se nos va, inevitablemente, hacia la necesidad de deconstruir y reconstruir buena parte de la tradicional teología de la revelación...

A pesar de todas las sombras que persisten, hoy sabemos no poco acerca de quiénes han sido los redactores anónimos de muchos de los textos de las Escrituras de las diferentes religiones. Con frecuencia no son las personas a quienes han sido atribuidas. Sin embargo, en la teología tradicional sobre la revelación ha sido

\footnotetext{
${ }^{33}$ Véase el número de la revista HORIZONTE de la PUC de Minas de Belo Horizonte, monográfico sobre "Paradigma pós-religional”, vol. 13, número 37, 660 pp., con la participación de los autores que más se han significado sobre el tema en los últimos años, en: <http://periodicos.pucminas.br/index.php/horizonte/issue/view/682/showToc>. Puede ser recogido en un solo archivo en servicioskoinonia.org/LibrosDigitales. Véase también la propuesta de la EATWOT, en la revista VOICES (<http://eatwot.net/VOICES〉), número January-March 2012, monográfico sobre el tema.
} 
común reconocer a Dios no sólo como el inspirador directo de las palabras del texto de los libros santos, sino como quien ha dictado materialmente su contenido. En buena parte de la teología de la revelación Dios mismo ha sido considerado como el "autor" de la Escritura (BARUQ; CAZELLES, 1965, p. 42), lo cual ha dado a ésta, a sus textos, a sus palabras, el carácter absoluto propio de lo divino. Atribuir a Dios la autoría de tradiciones, relatos, textos que nosotros mismos hemos creado, ha sido un mecanismo común en la historia de las religiones, que ha servido para absolutizar y preservar fuera de discusión normas, creencias, tradiciones... que la sociedad quería "blindar" frente a cualquier duda. Lo que hoy sabemos por la nueva arqueología nos obliga a lamentar los errores y sufrimientos padecidos por la humanidad a causa del espejismo de la atribución mítica de la Escritura a la autoría de Dios. Y nos pone en la necesidad de un cambio radical de paradigma en este cambio: las Escrituras no son palabra de Dios, sino palabra humana sobre Dios, como ya sostenía lúcidamente Edward SCHILLEBEECKX (1974, p. 72-73)34.

Junto a esto, es inevitable recordar conceptos tradicionales dentro de la teología de la revelación que han estado al uso durante muchos siglos en la Iglesia cristiana: sobre la "inerrancia" de la Escritura, sobre la "unicidad" de la Revelación, sobre la "inspiración divina" de que han gozado los escritores humanos, que han sido "instrumentos en las manos de Dios" para transcribir lo que Dios les dictaba... Resultando finalmente que la misma Escritura venía a ser una "carta de Dios" 35 directamente venida del cielo para los seres humanos (RAHNHER, 1979, p. 781790)...

El nuevo paradigma arqueológico nos invita a deconstruir tanta seguridad y dogmatismo edificado sobre bases de barro, míticas, hoy puestas al descubierto, para re-evaluar la validez de nuestro patrimonio simbólico, y proceder en adelante

\footnotetext{
34 "La palabra de Dios es la palabra de los hombres que hablan de Dios. Decir 'sic et simpliciter' que la Biblia es la palabra de Dios, no se corresponde con la verdad. Cuando la Biblia dice: 'Dios ha dicho, Cristo ha dicho...' no es Dios que lo ha dicho, no es Cristo quien lo ha dicho en sentido estricto, sino los hombres que han contado su experiencia de relación con Dios" (p. 72-73).

35 "El mundo es la carta que Dios le escribió a la Humanidad”, reza una frase atribuida a Platón. (MARTínEZ; ARSUAGA, 2004, p. 28).
} 
con mucha más humildad, pidiendo además perdón a todos los que hemos humillado en el camino por haber pensado de diferente manera ${ }^{36}$.

\section{Conclusión: Significado para una situación axial y evolutiva}

Siendo un episodio más de la conflictiva relación de la fe con la ciencia, ya hemos dicho que este paradigma de la nueva arqueología y su desafío no representan en realidad algo radicalmente nuevo; hemos vivido esta situación en otras ocasiones. Sin embargo, no se puede negar que tiene un valor emblemático, porque incide en pleno corazón de la fe religiosa, en el relato mismo que creíamos, denunciando su carencia de fundamento histórico objetivo. Hemos estado toda la vida creyendo... a nosotros mismos. Nunca como ahora estamos viendo que las formas religiosas (no la sustancia de la religiosidad misma) son creación nuestra, una genial "invención”. El nuevo paradigma arqueológico nos quita la última venda de nuestros ojos y nos invita a reconciliarnos con la verdad desnuda.

Somos la primera generación que se ve en una situación semejante. Durante milenios, las generaciones que nos han precedido han creído estar respondiendo de tú a tú- a la acción de Dios, que nos habría salido al encuentro en unos concretos acontecimientos históricos. Hasta hace menos de un siglo -y todavía hoy- muchos cristianos han entendido su fe como el asentimiento de confianza a palabras concretas del Jesús histórico, que nos habría informado de que él y el Padre son uno, y de que él había venido a decírnoslo. Todavía hoy, en los sectores conservadores y fundamentalistas, y hasta ayer en el conjunto del cristianismo e incluso de la civilización occidental, hemos estado convencidos de que La Biblia tenía razón y era un relato históricamente indubitable. Somos la primera generación que se ve desafiada a ser religiosa o espiritual sin hacer pie sobre apoyos históricos ilusorios. Este nuevo paradigma nos obliga a inaugurar una época

\footnotetext{
36 "Un solo error prueba que la Iglesia no es infalible. Un solo punto flaco prueba que un libro no es revelado [...]. En un libro divino todo es verdadero y no debe haber por tanto ninguna contradicción [...]. Un libro inspirado es un milagro; debería por lo mismo presentarse en condiciones únicas, distintas de las de cualquier otro libro" (RENÁN apud QUEIRUGA, 1987, p. 83).
} 
nueva para la fe, o a inaugurar una religiosidad nueva, para esta época en que la nueva arqueología nos despoja de ilusiones históricas.

En su libro A Secular Age, Charles Taylor sugiere que los cambios culturales de los últimos pocos siglos han creado una era de autenticidad. Todos nos vemos empujados a mirar dentro de nosotros mismos y a descubrir quiénes somos y cómo deberíamos vivir en este mundo. Taylor cree que esta situación colectiva ha creado "una nueva era de búsqueda religiosa" (TAYLOR, 2007, p. 437; VAN HAGEN, 2012, p. 246). Tal vez podemos decir algo semejante respecto al desafío del que estamos tratando: si este paradigma nos desafía a superar la ingenuidad con que estábamos creyendo, sobre la base del relato bíblico, desplazado ahora por "el relato que está detrás del relato bíblico”, ello nos obliga a basar nuestra religiosidad en este nuevo relato... Se va a tratar de una nueva religiosidad, porque se basa en un relato nuevo, hasta ahora desconocido.

La demolición de muchas de nuestras certezas históricas relativas a la fe, que la ciencia - la nueva arqueología en este caso- ha llevado a cabo, no es una catástrofe, ni nos aboca a un nihilismo destructor... sino que nos invita a la aceptación de lo real, y nos da una oportunidad de crecimiento, hacia una "calidad humana” (espiritualidad) purificada y más profunda, más allá de los relatos míticos en los que con toda ingenuidad nos hemos apoyado tradicionalmente y que tan bien cumplieron su papel, que parece estar quedando superado. La religión necesita revisarlo casi todo y reinventarse: necesita optar por un futuro diferente, un futuro que no sea mera proyección del presente. Tal vez todo ello sea parte de la nueva "gran transformación" que está en curso, de un segundo "tiempo axial" en el que nos estaríamos adentrando, de una más profunda "humanización de la humanidad”, o quién sabe si de una "segunda hominización”37.

\footnotetext{
${ }^{37}$ VIGIL, 2005, cap. 17: Hacia un nuevo tiempo axial; ARMSTRONG, 2006; ARMSTRONG, 2007; BELLAH; JOAS, 2012; VIGIL, 2015, p. 319359. De "segunda hominización" hablaba ya Teilhard de Chardin, adelantándose a esta visión, en La planétisation humaine (TEILHARD DE CHARDIN, 1959, p. 169).
} 


\section{REFERENCIAS}

ANDERSON, P.W. More Is Different. Science, Whashington, Vol. 147, No. 4047, p. 393396, Aug. 4, 1972.

ARMSTRONG, Karen. The Great Transformation. The begining of religious traditions. Toronto, Canadá: Random House, 2006.

ARMSTRONG, Karen. La gran Transformación: el mundo en la época de Buda, Sócrates, Confucio y Jeremías, el origen de las tradiciones religiosas. Barcelona: Paidós, 2007.

ARNOLD, Simón Pedro. La era de la mariposa. Una espiritualidad para tiempos de crisálida. Buenos Aires: Editorial Claretiana, 2015.

BARUQ, A.; CAZELLES, H. Los libros inspirados. En: ROBERT, A.; FEUILLET, A. (Ed.). Introducción a la Biblia. Barcelona: Herder, 1965. p. 35-90.

BELLAH, Robert; JOAS, Hans. The Axial Age and Its Consequences. London: Harward University Press, 2012.

BERGERON, Richard. Fora da Igreja também há salvação. São Paulo: Loyola, 2009.

BERGERON, Richard. Hors de l'Église plein de salut: pour une théologie dialogale et une spiritualité interreligieuse. Montreal: Médiaspaul, 2004.

BRIEND, Jacques; ARTUS, Olivier; NÖEL, Damien. Arqueología, Biblia, Historia. Cuaderno Bíblico n. 131. Estella: Verbo Divino, 2006. Disponible en:

<http://www.mercaba.org/SANLUIS/CUADERNOS_BIBLICOS/131\%20Arqueolog\%C3\% ADa,\%20biblia,\%20historia\%20\%20(VARIOS\%20AUTORES).pdf>. Consultado en: 27 de junio de 2016.

CORRADINI, Luisa. Entrevista a Israel Finkelstein. La Nación, Buenos Aires, el 25 de enero de 2006 [la edición impresa].

DAVIES, Philip; FRITZ, Volkmar (Ed.). The Origins of the Ancient Israelite States, Sheffield: Sheffield Academic Press, 1996.

DEL OLMO, Gregorio. Origen y persistencia del judaísmo. Estella: Verbo Divino, Estella, 2010.

DEVER, William G. Did God Have a Wife? Archeology and folk religión in ancient Israel. Cambridge UK: Eerdmans, 2005.

DEVER, William G. Who Were the Early Israelites and Where Did They Come From? Cambridge UK: Eerdmans, 2001a.

DEVER, William G. What Did The Biblical Writer Know \& When Did They Know It. Michigan: Eerdmans, 2001b. 
EHRMAN, Bart. Cristianismos perdidos. Los cristianismos proscritos del Nuevo Testamento. Barcelona: Ares y Mares, 2004. (Original: EHRMAN, Bart. Lost

Christianities. The battles for Scripture and the faiths we never knew. Oxford: Oxford University Press, 2003a).

EHRMAN, Bart. Lost Scriptures: Books that did not make it into the New Testament. Oxford: Oxford University Press, 2003b.

FINKELSTEIN, I. SILBERMAN, N.A. The Bible Unearthed: Archaeology's New Vision of Ancient Israel and the Origin of Its Sacred Texts. New York: Free Press, 2001. Versión española: La Biblia desenterrada. Una nueva visión arqueológica del Antiguo Israel y de los orígenes de sus textos sagrados. Madrid: Siglo XXI Editores, 2003, p 312 (Disponible en: <http://www.mercaba.org/Biblia/La\%2oBiblia\%2oDesenterrada.pdf>), Versión brasileña: A Bíblia não tinha razão. São Paulo: Editora A Girafa, 2003; Versión francesa: La Bible dévoilée. Les nouvelles révélations de l'archéologie. Paris: Bayard, 2001.

FINKELSTEIN, Israel. David and Solomon: in Search of the Bible's Sacred Kings and the Roots of the Western Tradition. New York: Free Press, 2006. (Versión española: David y Salomón. En busca de los reyes sagrados de la Biblia y de las raíces de la tradición occidental. Madrid: Siglo XXI, 2007).

HARARI, Yuval Noah. Sapiens: a brief history of humankind. New York: Random House, 2014. (En español: De animales a dioses. Breve historia de la Humanidad. Barcelona: Debate, 2014).

HODDER Ian \& HUDSON Scott. Reading the past. Current Approaches to Interpretation in Archaeology. Cambridge: Cambridge University Press, 2003.

KAEFER, Ademar. A Bíblia como fonte histórica. A Bíblia, a arqueología e a história. VOICES, Panamá, vol. 38, n. 3-4, p. 39-51, 2015.

KELLER, Werner. Y la Biblia tenía razón: la verdad histórica comprobada por las investigaciones arqueológicas. Barcelona: Omega, 1956 (y 1990). (Versão em português: E a Bíblia tinha razão. São Paulo: Ed. Melhoramentos, 3. ed. 2012; Versión inglesa: The Bible as History; a confirmation of the Book of Books. New York: Barnes \& Noble Books, 1995). [original of 1956: New York: Ed. W. Morrow].

LIVERANI, Mario. El Antiguo Oriente. Historia, sociedad, economía. Barcelona: Crítica, 1995. (In English: The Ancient Near East. History, Society and Economy. London/New York: Routledge, 2014.

LIVERANI, Mario. Oltre la Bibbia. Storia antica di Israele. Roma: Editori Laterza, 2003. (En español: Más allá de la Biblia. Historia Antigua de Israel. Barcelona: Editorial Crítica, 2005; In English: Myths and Politics in Ancient Near Easter Historiography. London: Equinox, 2004. En français: La Bible et l'invention de l'histoire. Histoire Ancienne d'Israel. Paris: Bayard, 2008. In English: Israel's History and the History of Israel. Translated by Ch. Peri \& Philip Davies. Equinox, London \& Oakville, 2005. 
MARSTON, Charles. The Bible is true; the lessons of the 1925-1934 excavations in Bible lands summarized and explained. London: Eyre and Spottiswoode, 1934.

MARTÍNEZ, I.; ARSUAGA, J.L. Amalur. Madrid: Ediciones Temas de Hoy, 2004.

MILLER, J. M.; HAYES, J. A History of Ancient Israel and Judah. Philadelphia: Westminster Press, 1986.

MOINGT, Joseph. Croire quand même. Paris: Temps Présent, 2010.

MYRE, André. La Source des paroles de Jésus. Montreal: Novalis, 2011.

NÚÑEZ DE CASTRO, I. Emergencia, vida y autotranscendencia activa. En: BERMEJO, Diego; ARREGI, Joxe et al. Pensar después de Darwin: ciencia, filosofía y teología en diálogo. Madrid: Universidad de Comillas, 2014. p. 169-212.

QUEIRUGA, A. Torres. La Revelación de Dios en la realización del hombre. Madrid: Cristiandad, 1987. (Edición revisada y ampliada: Repensar la revelación. La revelación divina en la realización humana. 2. Ed. Madrid: Trotta, 2008.

RAHNER, K. Inspiración. En: RAHNER, K. Curso Fundamental de Teología. Madrid: Cristiandad, 1979. p. 781-790.

SAND, Shlomo. Comment le peuple juif fut inventé. Paris: Fayard, 2008. (traducción española: La invención del pueblo judío. Madrid: Akal, 2011; traducción al inglés: The Invention of the Jewish People, London-New York: Verso, 2009).

SAND, Shlomo. The Invention of the Land of Israel. Tel Aviv: Kinneret Zmora-Bitan Dvir, 2012. (traducción española: La invención del pueblo de Israel. Madrid: Akal, 2011).

SCHILLEBEECKX, Edward. Soy un teólogo feliz. Madrid: Sociedad de Educación Atenas, 1974.

SERVICIOS KOINONIA. Bibliografía en línea sobre Nuevos Paradigmas. Disponible en: <http://servicioskoinonia.org/BibliografiaNuevosParadigmas.pdf >. Consultado en: 27 de junio de 2016.

TAYLOR, Charles. A Secular Age. Cambridge: Belknap Press of Harvard University Press, 2007.

TEILHRAD DE CHARDIN, Pierre. La planétisation humaine. En: Oeuvres, vol. 5: L'Avenir de l'homme, Paris: Seuil (Centre de recherches et d'expression mondialiste) 1959. [reeditado en 2009, por Points Sagesse].

THEISSEN, Gerhard. Sociología del movimiento de Jesús. El nacimiento del cristianismo primitivo. Santader: Sal Terrae, 1979.

THOMPSON, T. L. The Historicity of the Patriarchal Narratives: The Quest for the Historical Abraham, New York, Walter de Gruyter, 1974. 
THOMPSON, T. L. The Mythic Past: Biblical Archaeology and the Myth of Israel. New York: Basic Books, 1999.

THOMPSON, Thomas L. Early History of the Israelite People, from writen and archaeological sources. Leiden, Nederland: Brill Academic Publishers, 2000.

VAN HAGEN, John. Rescuing Religion. How faith can survive its encounter with science. Salem, Oregon, USA: Polibridge Press, 2012.

VIDAL MANZANARES, César. El judeo-cristianismo palestino en el siglo I. Madrid: Trotta, 1995.

VIGIL, J.M. Humanizar la Humanidad. El papel futuro de la religión. Horizonte, Belo Horizonte, v. 13, n. 37, p. 319-359, 2015.

VIGIL, José María. Teología del pluralismo religioso. Quito: Abya Yala, Quito 2005.

WHITELAM, Keith W. The Invention of Ancient Israel. Siencing of Palestinian History, Routledge, first published 1996, reprinted 2001. 


\section{ANEXO}

CORRADINI, Luisa. Entrevista a Israel Finkelstein. La Nación, Buenos Aires, el 25 de enero de 2006 [la edición impresa].

En dos siglos de investigación científica, la búsqueda de los patriarcas nunca dio resultados positivos. La supuesta migración hacia el Oeste de tribus provenientes de la Mesopotamia con destino a Canaán, se reveló ilusoria. La arqueología ha probado que en esa época no se produjo ningún movimiento masivo de población. El texto bíblico da indicios que permiten precisar el momento de la composición final del libro de los Patriarcas. Por ejemplo, la historia de los patriarcas está llena de camellos. Sin embargo, la arqueología revela que el dromedario sólo fue domesticado cuando se acababa el segundo milenio anterior a la era cristiana y que comenzó a ser utilizado como animal de carga en Medio Oriente mucho después del año 1000 a.C.

Según la Biblia, los descendientes del patriarca Jacob permanecieron 430 años en Egipto antes de iniciar el éxodo hacia la Tierra Prometida, guiados por Moisés, a mediados del siglo XV a.C. Otra posibilidad es que ese viaje se haya producido dos siglos después. Los textos sagrados afirman que 600.00o hebreos cruzaron el Mar Rojo y que erraron durante 40 años por el desierto antes de llegar a Canaán, pasando por el monte Sinaí, donde Moisés selló la alianza de su pueblo con Dios. Sin embargo, los archivos egipcios, que consignaban todos los acontecimientos administrativos del reino faraónico, no conservaron ningún rastro de una presencia judía durante más de cuatro siglos en su territorio. Tampoco existían, en esas fechas, muchos sitios mencionados en el relato. Las ciudades de Pitom y Ramsés, que habrían sido construidas por los hebreos esclavos antes de partir, no existían en el siglo XV a.C.

En cuanto al Éxodo, desde el punto de vista científico no resiste el análisis. En efecto, desde el siglo XVI a.C., Egipto había construido en toda la región una serie de fuertes militares, perfectamente administrados y equipados. Nada, desde el 
litoral oriental del Nilo hasta el más alejado de los pueblos de Canaán, escapaba a su control. Casi dos millones de israelitas que hubieran huido por el desierto durante 40 años tendrían que haber llamado la atención de esas tropas. Sin embargo, ni una estela de la época hace referencia a esa gente. Ni siquiera hay rastros dejados por esa gente en su peregrinación de 40 años. Hemos sido capaces de hallar rastros de minúsculos caseríos de 40 o 50 personas. A menos que esa multitud nunca se haya detenido a dormir, comer o descansar: no existe el menor indicio de su paso por el desierto.

Tampoco existieron las grandes batallas mencionadas en los textos sagrados. La orgullosa Jericó, cuyos muros se desplomaron con el sonar de las trompetas de los hebreos, era entonces un pobre caserío. Tampoco existían otros sitios célebres, como Bersheba o Edom. No había ningún rey en Edom para enfrentar a los israelitas. Esos sitios existieron, pero mucho tiempo después del Éxodo, mucho después del surgimiento del reino de Judá.

Los hebreos nunca conquistaron Palestina, porque ya estaban allí. Los primeros israelitas eran pastores nómadas de Canaán que se instalaron en las regiones montañosas en el siglo XII a.C. Allí, unas 250 comunidades muy reducidas vivieron de la agricultura, aisladas unas de otras, sin administración ni organización política. Todas las excavaciones en la región exhumaron vestigios de poblados con silos para cereales, pero también de corrales rudimentarios. Esto nos lleva a pensar que esos individuos habían sido nómadas que se convirtieron en agricultores. Pero ésa fue la tercera ola de instalación sedentaria registrada en la región desde el 3500 a.C. Esos pobladores pasaban alternativamente del sedentarismo al nomadismo pastoral con mucha facilidad.

Tampoco en el caso de la monarquía unificada con David y Salomón la arqueologia ha sido capaz de encontrar pruebas del imperio que nos legó la 
Biblia38: ni en los archivos egipcios ni en el subsuelo palestino. David, sucesor del primer rey, Saúl, probablemente existió entre 1010 y 970 a.C. Una única estela encontrada en el santuario de Tel Dan, en el norte de Palestina, menciona "la casa de David". Pero nada prueba que se haya tratado del conquistador que evocan las Escrituras, capaz de derrotar a Goliat. Es improbable que David haya sido capaz de conquistas militares a más de un día de marcha de Judá. La Jerusalén de entonces, escogida por el soberano como su capital, era un pequeño poblado, rodeado de aldeas poco habitadas39. ¿Dónde el más carismático de los reyes hubiera podido reclutar los soldados y reunir el armamento necesarios para conquistar y conservar un imperio que se extendía desde el Mar Rojo, al Sur, hasta Siria, al Norte? Salomón, constructor del Templo y del palacio de Samaria, probablemente tampoco haya sido el personaje glorioso que nos legó la Biblia.

Hacia fines del siglo VII a.C. hubo en Judá un fermento espiritual sin precedentes y una intensa agitación política. Una coalición heteróclita de funcionarios de la corte sería responsable de la confección de una saga épica compuesta por una colección de relatos históricos, recuerdos, leyendas, cuentos populares, anécdotas, predicciones y poemas antiguos. Esa obra maestra de la literatura -mitad composición original, mitad adaptación de versiones anteriorespasó por ajustes y mejoras antes de servir de fundamento espiritual a los descendientes del pueblo de Judá y a innumerables comunidades en todo el mundo.

El núcleo del Pentateuco fue concebido, entonces, quince siglos después de lo que creíamos. El objetivo fue religioso. Los dirigentes de Jerusalén lanzaron un anatema contra la más mínima expresión de veneración de deidades extranjeras, acusadas de ser el origen de los infortunios que padecía el pueblo judío. Pusieron

\footnotetext{
38 Ni David ni Salomón son citados en un solo documento conocido de Egipto ni de Mesopotamia. Cfr. FINKELSTEIN, La Biblia desenterrada, 2001, p. 130.

${ }^{39}$ Diferentes autores ponen seriamente en duda la existencia de una estructura urbana desarrollada en Jerusalén antes del siglo VIII antes de nuestra era. De hecho, las actuales ruinas de la "ciudad de David" están muy lejos de permitir pensar que fueran la base administrativa de un imperio davídico como el descrito por la Biblia. También la "teoría documentaria" caería por el suelo, al ser igualmente imposible un cuerpo instruido de escribas que fuese autor del documento yahvista supuestamente escrito en Jerusalén durante el reinado de David o Salomón.
} 
en marcha una campaña de purificación religiosa, ordenando la destrucción de los santuarios locales. A partir de ese momento, el templo que dominaba Jerusalén debía ser reconocido como único sitio de culto legítimo por el conjunto del pueblo de Israel. El monoteísmo moderno nació de esa innovación. 